\title{
Mi változna Budapest számára a területi statisztikai régió kettéválasztásával?
}

\section{What would change after the division of Central Hungary regarding the regional role of Budapest?}

\author{
SZEGVÁRI PÉTER
}

\begin{abstract}
SZEGVÁRI Péter: önkormányzati tanácsadó, Budapest Főváros Főpolgármesteri Hivatal Főpolgármesteri Iroda; 1052 Budapest, Városház u. 9-11.; szegvarip@budapest.hu
\end{abstract}

Péter SZEGVÁRI: senior advisor to Lord Mayor of Budapest, Cabinet of the Lord Mayor, Lord Mayor's Office, Municipality of the City of Budapest; Városház u. 9-11., H-1052 Budapest, Hungary; szegvarip@budapest.hu

Budapest Főváros Önkormányzatának Közgyülése 2015. december 2-i ülésén a jelen lévő képviselők egyhangú szavazatával támogatta a Közép-Magyarország régió jelenlegi közigazgatási határok mentén történő kettéválasztását a Budapest és Pest megye területét lefedő önálló NUTS 2 egységekre. Továbbá támogatta azt is, hogy Budapest Főváros Önkormányzata és Pest Megye Önkormányzata között korábban létrejött tervezési-együttműködési megállapodás alapján ${ }^{1}$ a létrejövő két régió regionális és területfejlesztési tervezésénél továbbra is legyen együttmúködés, biztosítva ezzel Budapest és térsége együttes és összehangolt tervezését és programozását.

A cikkben megpróbálom értelmezni, hogy milyen szempontok vezettek ahhoz, hogy Budapest Főváros Önkormányzata támogatta a kormány kezdeményezését a Közép-Magyarország területi statisztikai régió kettéválasztásáról. Közép-Magyarország területi statisztikai régió kettéválasztásának kérdése nemcsak szakmai, hanem jelentősen politikai kérdés is, ahogyan azt a korábbi, az EU-csatlakozást megelőző időszakban is láttuk. 2004-ben ebben a kérdésben Pest megye és Budapest önkormányzati vezetőinek homlokegyenest más véleménye volt, a Fővárosi Közgyűlés sem területfejlesztési-szakmai okokból, sem a közigazgatási reform szempontjából nem tartotta kívánatosnak, hogy a fóvárost és a környezetét más régióba helyezzék. ${ }^{2}$ Vajon mi lehet az oka annak, hogy most a Fővárosi Közgyülés másként - a Pest Megyei Közgyűléssel azonos módon - foglalt állást ebben a kérdésben?

Egyrészt a Fővárosi Közgyűlés a 2004-ben elfogadott állásfoglalásában arra hivatkozott, hogy területfejlesztési szempontból a régiónak egyben kell marad-

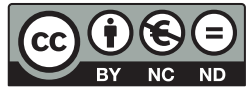


nia, másrészt abban a reményben döntött így, hogy az akkori kormány közigazgatási reformprogramja megvalósul, s ennek keretében Budapest és agglomerációja közigazgatási-közhatalmi régióvá válhat. Az akkori kormánydöntéshez készült minisztériumi háttéranyag kifejtette, hogy területfejlesztési szakmai szempontból Közép-Magyarország kettéválasztása kedvezőtlen hatású, és a régió egyben maradását kell előtérbe helyezni, de megállapította, hogy a kedvezőtlen területfejlesztési hatások enyhíthetők az agglomerációnak tervezési egységként való kezelésével. Ugyancsak fontosnak minősült a régió egyben tartásánál az is, hogy pénzügyi szempontból Magyarország viszonylag kis veszteséggel is számolhatott volna a régió kettéválasztása esetén, hiszen Budapesten valószínűleg az átmeneti (phasing-in) támogatás elmaradt volna a 2007-2013 közötti periódusban (NGM 2015, 24-26.).

A jelenlegi döntés során fontos megjegyezni, hogy a kettéválasztás csak a következő programozási időszaktól határozná meg Budapest és Pest megye EU-forrásokból és hazai területfejlesztési eszközökből történő támogathatóságát, amelyeknek a szabályait még nem dolgozták ki, ezért nehéz erre az időszakra kivetíteni a régió jelenlegi helyzetét. Annyi azonban rögzíthető, hogy Közép-Magyarország EU 27-átlaghoz mért magas egy före jutó GDP-értéke miatt a régió ma már a fejlettebb régiók kategóriájába tartozik, döntő részben a főváros teljesítményének köszönhetően. A Közép-Magyarország régió egy före jutó bruttó hazai terméke vásárlóerő-paritáson az EU 27 átlagának százalékában a 2007-es 101,5\%-ról 2011-re 110,0\%-ra növekedett, miközben Pest megye értéke azonos időszakban 57,4\%-ról 56,6 \%-ra csökkent (Eurostat-adatok). Elmondható, hogy a régió szétválása után - az EU 2014-2020 közötti szabályainak figyelembevételével - Budapest várhatóan továbbra is a fejlettebb régiókategóriába tartozna, vagyis a Pest megye számára potenciálisan rendelkezésre álló EU-forrástöbblet nincs közvetlen összefüggésben a Budapest számára elérhető pénzügyi források alakulásával. Sőt a szétválásnak olyan hozadéka is lehet, hogy a budapesti beruházások és befektetések állami támogatásánál Budapest területére is meghatározható lesz magasabb állami támogatási intenzitásra jogosult térség, ami eddig csak Pest megyére korlátozódott. ${ }^{3}$ Ez a lehetőség - amennyiben a szabályozás nem változik - előnyösebb forrásallokációt biztosíthat az átlaghoz képest relatíve elmaradottabb, főként a Pest megye határával szomszédos fővárosi kerületek számára.

Budapest önálló NUTS 2 régióvá válása esetén a 2020 utáni európai uniós programozási időszakban már önálló, kizárólag Budapest területére fókuszáló területi operatív program készülhet, ami a korábbi időszakokhoz képest jelentősebb érdekérvényesítést tenne lehetővé a főváros számára, főként, ha megvalósulna a tervszerződés intézményrendszere, amely hétéves tervidőszakra előre meghatározná a területi operatív programokhoz hozzárendelhető EU-s és állami források mértékét. Pest megye önálló régióvá válása esetén - a kevésbé fejlett régiókhoz hasonlóan - várhatóan több európai uniós forrás lehívására lesz jogosult, ami a fővárossal közösen megvalósuló, városhatáron átívelő fejleszté- 
sek esetében nagyobb arányú területi alapú hozzájárulást is feltételezhet. Ez különösen megerősíti a két önkormányzat között létrejött megállapodás alapján Budapest és Pest megye együttes regionális és területi tervezését és összehangolt programozását.

Ugyancsak más a helyzet a korábbiakhoz képest a regionális önkormányzatiság témakörében, hiszen 2011-től eldőlt, hogy a megyei és a fövárosi önkormányzatok töltik be a területi, európai értelemben regionális önkormányzatok szerepét. A NUTS 2 szintű régiókban is a megyék és a főváros önkormányzatai felelösek a területfejlesztési feladatok ellátásáért, s mindazokban az esetekben, amikor Budapest vagy Pest megye területén túlmutat egy-egy területfejlesztési ügy, szükséges az érintett önkormányzatok közötti koordináció, illetve a harmonikus döntéshozatal kereteinek megteremtése. ${ }^{4}$ A korábban már említett, 2012-ben Budapest és Pest megye önkormányzata között létrejött együttműködési megállapodás keretében 2013 óta konzultációs fórumot működtetnek a területfejlesztési elképzelések összehangolására. A megállapodás értelmében szakmai egyeztetésekkel készítik elő például az utak felújítását, a közművezetékek korszerüsítését célzó feladatok összhangját és a gazdasági fejlesztéseket.

2014 januárjától a Fővárosi Önkormányzat intenzív partnerségi tervezési folyamatot koordinált a kerületi önkormányzatok és Pest Megye Önkormányzatának részvételével három kiemelt témában, melyeket a fejlesztési igények figyelembevételével a Budapest 2030 hosszú távú városfejlesztési koncepció előzetesen azonosított. Ezek a Duna menti területek összehangolt fejlesztése, a barnamezős területek fejlesztése és a szociális városrehabilitáció voltak. A részvételi tervezési folyamat célja a városfejlesztés keretében ún. tematikus fejlesztési programok (TFP) kidolgozása volt, ami a közös fejlesztési irányvonalak meghatározásán túl az európai uniós források által finanszírozható projektek beazonosítását és előkészítését is magában foglalta. A folyamat eredményeképp a Fővárosi Közgyűlés által elfogadott három stratégiai tervezési dokumentum elfogadásával egyidejűleg, a részt vevő kerületi önkormányzatok egyhangúan megszavazott döntése alapján egy negyedik, a gazdaságélénkítést és munkahelyteremtést elősegítő tematikus fejlesztési program is elkészült 2015 első félévében. Az elfogadott stratégiák megalkotása széles körü folyamatos együttműködést igényelt, így jól működő partnerség alakult ki a folyamatban részt vevő Fővárosi Önkormányzat, a fővárosi kerületek és Pest megye között. A Közép-Magyarország régió statisztikai kettéválása esetén a tematikus fejlesztési programok során alkalmazott tervezési módszertan megfelelő lehet Pest megye és Budapest összehangolt fejlesztési elképzeléseinek kialakításához a jövőben.

Akárhogy is alakul a kohéziós politika működése 2020 után, Budapestet és térségét - beleértve a szükebb (intenzív) és a jelenlegi Közép-Magyarország régió területét is magában foglaló tágabb (extenzív) agglomerációt - mindenképpen érdemes a nemzetközi szerep és az egyre bővülő vonzáskörzet, valamint a ténylegesen mủködő kapcsolatok miatt egységes térségként, egyfajta metropoliszrégióként kezelni. A főváros és környéke között olyan erős és szerves kap- 
csolatok alakultak ki, hogy - az uniós források régiótípusonként eltérő támogatási kritériumai ellenére - alapvetően hazai gazdaság- és területfejlesztési forrásokból továbbra is fenn kell tartani a főváros pozitív hatását. A közigazgatási és fejlesztéspolitikai önállósulás nem az elkülönülés, a bezárkózás kezdetét kell, hogy jelentse, hanem a még hiányzó igazgatási, szolgáltatásellátási koordináció kiépítésének elindítását. Budapest európai metropoliszként csak akkor lehet versenyképes az EU más nagyvárosaival, ha a regionális és makroregionális fejlesztésekben - közigazgatási és területfejlesztési régiókhoz való tartozástól függetlenül - együttműködik a várostérségben müködő önkormányzatokkal, s ehhez összehangolt térségfejlesztési intézményrendszert épít ki, speciális finanszírozási eszközt használ, és célszerü munkamegosztást alakít ki a partnereivel.

Összességében kijelenthető, hogy az önálló NUTS 2 szintű statisztikai régiók létrehozása kizárólag a NUTS-besorolás módosítását jelentené, mely Budapest esetében nincs közvetlen hatással sem a közigazgatási rendszer átalakítására, sem a városfejlesztési vagy területfejlesztési politikára.

\section{Jegyzetek}

1 A Fővárosi Közgyűlés 2012. december 12-én egyhangú szavazattal hagyta jóvá 2936/2012. (XII. 12.) sz. határozatával a megállapodást, amelyet Budapest és Pest megye képviselői 2013. április 4-én írtak alá a Városházán.

2 A Fővárosi Közgyűlés 2004. szeptember 30-án fogadta el ezzel kapcsolatban az 1687-1689/2004. (IX. 30.) sz. határozatait.

3 Lásd az Európai Unió működéséről szóló szerződés 107. cikke (3) bekezdésének a) és c) pontját.

4 Vö. A területfejlesztésről és a területrendezésről szóló 1996. évi XXI. törvény 14/A.\$-ával.

\section{Irodalom}

NGM (2015): A Közép-magyarországi régió esetleges kettéválasztásának lehetőségéról szóló vizsgálat. Nemzetgazdasági Minisztérium, Budapest 